\title{
Caspase Gene
}

National Cancer Institute

\section{Source}

National Cancer Institute. Caspase Gene. NCI Thesaurus. Code C26552.

These genes encode caspases, a family of intracellular cysteine proteinases involved in inflammation and apoptosis. These enzymes appear to be involved in the initial signaling events, as well as the downstream proteolytic cleavages, that result in apoptotic cell death. They are specific for aspartic acid at the P1 position and are divided into two classes based on the lengths of their $\mathrm{N}$-terminal pro-domains. Caspases-1, - 2, -4, -5, -8, and -10 have long pro-domains while caspases-3, -6, -7, and -9 have short pro-domains. (from Science 1998. 281:1312 and Br Med Bull 1997. 53:478) 